\title{
Cultural additivity: Questions for evolutionary thinkers
}

\author{
Manh-Tung Ho \\ Ritsumeikan Asia Pacific University \\ Beppu, Oita, Japan
}

September 23, 2021

Cultural additivity is a major discovery of Prof. Quan-Hoang Vuong and his associates [1-3]. In the 2018 paper, this phenomenon was defined as: "a mechanism whereby people of a given culture are willing to incorporate into their culture the values and norms from other systems of beliefs that might or might not logically contradict with principles of their existing system of beliefs" (p.2). The author and his team further explicate other concepts related to this phenomenon of adding new values into one's native cultural value system, namely syncretism, cultural hybridity, and creolization in a recent encyclopedia entry [4]. I strongly recommend readers visit these resources to explore the conceptual analyses. This essay, however, focuses on speculating on the evolutionary dynamics that give rise to cultural additivity.

\section{High-additivity culture versus low-additivity culture}

This section aims to highlight the two ends of the cultural additivity spectrum, which is important for evolutionary reasoning. Successful evolutionary reasoning about cultural additivity must account for both ends of the spectrum.

Whenever new values emerge or are introduced into native culture, individuals of a culture system have two potential strategies: either adding these values into their cultural core or rejecting them to protect the purity of the core values. In the scholarly works on cultural additivity, Vuong et al. find that contradicting values of Confucianism, Taoism, and Buddhism can often coexist [1]. Later, studying cultural additivity in the realm of Vietnamese architecture, the authors find traditional symbols from the Three Eastern Religions can blend in with symbols from French-style architecture for an aesthetic purpose [2]. To illustrate the phenomenon, Vuong et al. cited the example of Caodai-ism, which was founded in 1926. This particular religion has brought together elements of the East and the West by worshipping Buddha, Lao Tzu, Victor Hugo, Confucius, Jesus Christ, or Jade Emperor (Ngọc Hoàng) and the Holy Spirit to be one. 
Value-addition can be a potent social strategy for solving various social problems: promoting social harmony, signaling virtues and classes, etc. Yet, there are many examples of people within a culture reject all the introduction of new values and norms. The culture of a religious fundamentalist, for instance, is all about systematically rejecting or subtracting any changes that contradict what they think are true faiths [5]. Even among people who call themselves progressives on the left, there are also many cases of people rejecting what they think contradicts their values and identities. In the phenomenon of the cancel culture, people who signal the wrong messages and values are punished with reputational damages, public shaming, and sometimes even violence [6].

These examples show that, in certain cultures, people are more readily to go for the strategy of value-addition when confronting new, contradictory values. In others, people are more readily rejecting value changes. Thus, successful evolutionary reasoning of cultural additivity needs to specify circumstances in which people are more or less likely to add new contradictory values. Before diving into the evolutionary dynamics of cultural additivity, we will explore a new set of empirical findings that suggest people often add rather than subtract when solving a problem.

\section{Resistant to subtractive changes}

A series of new empirical results by Adams et al. (2021) [7] and popularized in the newly published book, Subtract: The Untapped Science of Less by Leidy Klotz [8] show that adding seems to be a default strategy in problem-solving. In these works, the authors show via a series of ingenious experiments that people systematically (i.e., by default) go to addition as a strategy to solve their problems. At the same time, they tend to overlook advantageous subtractive changes. In other words, humans are generally resistant to subtractive change. Adams et al. found similar rates of subtractive strategy among experimental subjects who were asked to transform block structures, essays, and itineraries. The authors argue whether it is about The authors invoke some of the famous heuristics that have been popularized in Kahneman and Tversky [9] such as loss aversion to explain these results and identify situations where people are more or less likely to overlook advantageous subtractive changes.

\section{Questions for evolutionary dynamics of cultural additivity}

Now that we know, people will often overlook subtraction as a strategy for making things better. But what does it mean for cultural additivity? Clearly, changes in the realm of cultural values are different from changes in situations presented to the experimental subjects in Adams et al. [7]. Values are interesting because to live a value 
fully, and one often needs to give up other values. For example, suppose you are raised in the honor culture, where defending your honor via violent means is the norm, to become a member of the dignity culture. In that case, you need to give up most of the important norms most associated with the honor culture [10].

How does an evolutionary psychology explanation work in the case of cultural additivity? First, in this speculating process, I am taking a hypothetical gene or a hypothetical set of genes for cultural additivity as a fundamental unit to analyze the evolutionary costs and benefits. It is also important to note that values and norms are abstract entities (or memes) that govern human behaviors and emotions. And they also seek to propagate to the next generation. Perhaps, here, there is a symbiotic relationship between human genes and cultural memes (in the forms of values and norms). The evolution of high-additivity culture is the case of the successful coevolution of this symbiotic relationship. But more on that later.

Second, in terms of evolutionary pressure on that hypothetical gene or a set of genes, in the study of cultural tightness-looseness, Gelfand et al. (2011) identified three categories of factors that influence the evolution of cultural tightness-looseness, i.e., the strength of social norms and the tolerance of deviant behavior. Those factors are ecological and historical threats (or lack thereof), human-made societal threats (or lack thereof) [11]. Gelfand et al. showed that the socialization of institutions (broad versus narrow) and strength of everyday situations (i.e., the number of constraints an everyday situation puts on an individual), and a person's self-regulation are manifestations of cultural tightness-looseness, which in turn is the results of effects from the three evolutionary pressures. Put simply, societies that experience high potential for dangers (resource-scarce, prevalence of natural disasters, high population density, prevalence of intergroup conflicts, etc.) tend to promote a tight culture, where social norms and values are strong and must be strictly observed. While societies that experience low potential for dangers (resource-rich, few natural disasters, low population density, few conflicts, etc.) tend to promote a loose culture, where social norms and values are weaker.

There is a crucial difference between cultural tightness-looseness and cultural additivity to be discussed. The explanatory process of the theory of cultural tightnesslooseness starts with the evolutionary pressures a culture or a nation faces then ends with the strength of their norms and values, meanwhile, for cultural additivity, the explanatory process starts with describing a set of core cultural values and then investigate how likely new values are added to such a culture. Thus, the theory of cultural tightness-looseness offers an evolutionary explanation of the stability of a given 
set of cultural core values, while cultural additivity provides a conceptual framework to explain how likely new values are added given what one knows about the current cultural core values. In other words, cultural additity, and its antecedent-the mindsponge process of value changes $[1-3,12,13]$ explores the Bayesian updating process of value changes. Given such crucial differences, I think for an evolutionary theorizing of cultural additivity to be successful, the theorizing process should consider the following questions.

First, should cultural additivity be treated as an evolved strategy for prolonging the survival of people carrying the hypothetical gene mentioned above as well as cultural memes? This is likely the case because of the symbiotic relationship between memes and genes, between culture and biology. Second, under which circumstances does cultural additivity, as an evolved strategy, becomes a favored strategy? Third, given human's resistance to subtractive changes mentioned above $[7,8]$, is it likely that the evolutionary balance always tips in favor of cultural additivity? Fourth, given the Bayesian updating explanatory process, how does cultural additivity theorists define a run-away threshold, where a newly added value taking over the core mindset, and influences the addition and rejection of new values, i.e., influences the evolution of the core mindset?

Fifth, there is a question regarding what kinds of things cultural additivity evolves to optimize for. It is useful to take a detour and invoke a critical concept the study of artificial intelligence and behavioral science: the exploration vs. exploitation tradeoff. An algorithm, a human, or an animal needs to decide whether to keep exploiting a local optimum or search for a global optimum [14]. In the context of cultural additivity, settling for a set of norms and values is equivalent to the exploitation strategy. While adding new norms and values and testing them before settling for a changed set of core values is equivalent to the exploration strategy (Here, it is useful here visit the mindsponge mechanism that seeks to explain the process of value addition and rejection $[12,13])$.

An example is useful here. Considering the impact of natural resources, there would be less evolutionary pressure in a rich natural environment to strictly observe a given set of norms and values. Individuals are allowed more material freedom to explore different ways of life. This would likely give rise to a higher-additivity culture. In a poorer natural environment, people would be more likely observe values and norms stricter. This means when encountering new values, the default mode will likely reject them because people have settled for a set of values and norms that are proven to work in stringent conditions. Adding any values might upset this local optimum. Thus, it 
is important for cultural additivity theorists to define what a global optimum means in the context of value changes because a global optimum might change with new values.

In conclusion, cultural additivity opens up many new theoretical and empirical questions to explore for evolutionary psychologists and anthropologists. In this essay, I hope I have succeeded in presenting a number of questions that evolutionary thinkers need to consider when pondering the evolution of cultural additivity. Understanding the evolution of culture will always be an important task that transcends the boundary of disciplines in the sciences [15]. Given the hyperconnectivity of the digital age, explaining the dynamics behind the addition and rejection of new values will carry implications for the processes of policy-making and educating citizens [16-18].

\section{References}

1. Vuong, Q.-H., Bui, Q.-K., La, V.-P., et al. (2018). Cultural additivity: behavioural insights from the interaction of Confucianism, Buddhism and Taoism in folktales. Palgrave Communications, 4(1), 143.

2. Vuong, Q.-H., Bui, Q.-K., La, V.-P., et al. (2019). Cultural evolution in Vietnam's early 20th century: A Bayesian networks analysis of Hanoi Franco-Chinese house designs. Social Sciences \& Humanities Open, 1(1), 100001.

3. Vuong, Q.-H., Ho, M.-T., Nguyen, H.-K. T., et al. (2020). On how religions could accidentally incite lies and violence: folktales as a cultural transmitter. Palgrave Communications, 6(1), 82.

6. Lukianoff, G., \& Haidt, J. (2019). The coddling of the American mind: How good intentions and bad ideas are setting up a generation for failure. New York: Penguin Books.

7. Adams, G. S., Converse, B. A., Hales, A. H., \& Klotz, L. E. (2021). People systematically overlook subtractive changes. Nature, 592(7853), 258-261.

8. Klotz, L. E. (2021). Subtract: The Untapped Science of Less. Flatiron Books.

9. Kahneman, D. (2011). Thinking, fast and slow. Macmillan.

10. Sommers, T. (2018). Why honor matters. New York: Basic Books.

11. Gelfand, M. J., Raver, J. L., Nishii, L., Leslie, L. M., Lun, J., Lim, B. C., Duan, L., Almaliach, A., Ang, S., \& Arnadottir, J. (2011). Differences between tight and loose cultures: A 33-nation study. Science, 332(6033), 1100-1104. 
12. Vuong, Q. H. (2016). Global mindset as the integration of emerging socio-cultural values through mindsponge processes: A transition economy perspective. In J. Kuada (Ed.), Global Mindsets: Exploration and Perspectives (pp. 109-126). London: Routledge.

13. Vuong, Q. H., \& Napier, N. K. (2015). Acculturation and global mindsponge: an emerging market perspective. International Journal of Intercultural Relations, 49, 354-367.

14. Mehlhorn, K., Newell, B. R., Todd, P. M., Lee, M. D., Morgan, K., Braithwaite, V. A., Hausmann, D., Fiedler, K., \& Gonzalez, C. (2015). Unpacking the explorationexploitation tradeoff: A synthesis of human and animal literatures. Decision, 2(3), 191.

15. Vuong, Q.-H. (2021). The semiconducting principle of monetary and environmental values exchange. Economics and Business Letters, 10(3), 1-9.

16. Vuong, Q.-H. (2020). Reform retractions to make them more transparent. Nature, 582(7811), 149. doi:https://doi.org/10.1038/d41586-020-01694-x

17. Vuong, Q.-H. (2018). The (ir)rational consideration of the cost of science in transition economies. Nature Human Behaviour, 2(1), 5-5. doi:10.1038/s41562017-0281-4

18. Phạm Minh Chính, Vương Quân Hoàng. (2009). Kinh tế Việt Nam: Thăng trầm và đột phá. Nxb Chính trị Quốc gia, Hà Nội. 